Preliminary communication UDC 1:81(045)Hobbes, T. 1:81(045)Reid, T.

doi: $10.21464 / \mathrm{sp} 32203$

Received: March 24, 2017

\title{
Ivana Knežić
}

Unversity of Zadar, Obala kralja Petra Krešimira IV. 2, HR-23000 Zadar iknezic@unizd.hr

\section{The Problem of Language Grounding} as a Specific Human Feature in the Philosophy of Thomas Hobbes and Thomas Reid

\begin{abstract}
The paper explores the foundation of language as a specific human ability in the works of two representatives of modern British philosophy: Thomas Hobbes and Thomas Reid. Both of them share the understanding of language as a specific human feature, through which human beings express their thoughts. In fact, according to Hobbes, language is not only a specific human ability but also the basic human ability which enables the formation of all other abilities - including rational thinking. It elevates human beings above the world of animals. Language, therefore, is not something that arises out of human nature, rather the opposite; it is something that, in a certain way, conditions the emergence of humanity itself. At the same time, the problem of grounding of language is left unsolved in the philosophy of Thomas Hobbes. Differently, even though Thomas Reid considered all the languages in the world as systems of artificial signs made by human beings, he grounded them in human nature itself, more precisely, in something he calls "natural language", common to all humans as rational and social beings. However, this attempt of grounding language in human nature faced some difficulties that made the solution, offered by this Scottish philosopher, inconsistent. Despite all the differences between the two philosophers, these difficulties imply their common philosophical background.
\end{abstract}

\section{Keywords}

Thomas Hobbes, Thomas Reid, language, nominalism, human nature

\section{Introduction}

Language is a part of human life with an unquestionably great importance. Much of the information we receive is by means of language and most of the things that we learn, we learn through language. That is why language seems to be a very effective means of actuating something, which Aristotle recognised as a natural tendency of human nature: our desire to know. ${ }^{1}$ In addition, we use sensible signs of language to express the intelligible acts of our mind and to communicate them to other human beings. Thereby, language clearly reveals the complex spiritual-corporeal natural constitution of men and the interdependence of these two dimensions of human beings. ${ }^{2}$ However, through

1

See: Aristotle, Metaphysics, in: Jonathan Barnes (ed.), The Complete Works of Aristotle. The Revised Oxford Translation, Princeton University Press 1984, reprint: 1995, p. 1552 (980 a 20).
2

See: Battista Mondin, Philosophical Anthropology, Theological Publications in India, Bangalore 2007, p. 143. 
language we do not only communicate our thoughts, but our desires and affections, too. Through language, we communicate love, as well as some social acts like contracts, covenants, promises, orders, etc. Thus, language also reveals the human relational dimension, or our social nature. All of this brings us to the conclusion which was common amongst ancient and medieval philosophers - language is something natural to men. Though the image of man has changed in modern philosophy, philosophers of that age still affirmed language as a specific feature of human beings. But did they see it as man's natural ability as well? Did they succeed in giving any solid ground to this human specificity?

This paper aims at answering these questions by inquiring into the works of two philosophers, two representatives of modern British philosophy: 17th century English philosopher Thomas Hobbes of Malmesbury and 18th century Scottish philosopher Thomas Reid of Aberdeen. It may rightly be said that neither of these is quite a typical representative of modern British philosophy; Hobbes because of his strong addiction to mathematical method in philosophy, which brings him somehow close to continental rationalists, and Reid because of his fierce critique of the theory of ideas directed at the most prominent British philosophers of the period. Nevertheless, both of them have a lot in common with these thinkers, not only when it comes to the time and place of their lives and works, but also when it comes to some basic philosophical principles. Hence, we may justly inquire into their writings in order to see what kind of solutions modern British philosophy offers to the problem of grounding of language as a specific feature of man. These philosophers give explicitly different answers to the first question posed, but they, nevertheless, face some similar problems in formulating their answers, which is why the answers to the second question is what will bring the two philosophers much closer to one another.

\section{Thomas Hobbes}

Thomas Hobbes is well known for his contractualistic theory of society and, accordingly, theory of natural condition of mankind, which he sees as a condition of perpetual war. According to this English philosopher, a man is a natural enemy to another man and their agreement and mutual cooperation is something that can be achieved only through social contract, which enables them to get out of their natural condition, where they find no safety and no flourishing of life. That means that the sociability is not something natural in the human world, but, quite the opposite, it is an artificial product of men. This way, the philosopher of Malmesbury overturns the ancient and medieval position according to which man is a social animal by nature, zoon politikon, and as Thomas Aquinas says, a natural friend to another man. ${ }^{3}$ This natural sociability of men, as Aristotle notices in his Politics, is closely related to another natural feature of men - the power of speech. The power of speech is also man's specific feature because he is the only animal whom the nature has endowed with this gift. That is why his sociability highly exceeds the sociability of other animals and he is the only living being that makes family and state. ${ }^{4}$ But if man is capable of making natural communities, like family and state, thanks to his natural gift of speech, we may wonder what happens with this natural gift when such communities become something artificial, as they are in the philosophy of Hobbes?

First of all, it is necessary to point out that this English philosopher shares Aristotle's view of speech as something peculiar to men. He also agrees with him 
that speech is something essential for the making of society, because without speech there would be amongst men "neither commonwealth, nor society, nor contract, nor peace, no more than amongst lions, bears, and wolves". According to Hobbes, "speech is the connection of words, established by the will of men, to signify the train of conceptions of things that we think about". 6 This definition might suggest that this English philosopher upholds the traditional view about the priority of reason in respect of language. In that case, language could be something natural to man if man is by his nature a thinking being. But is it really so?

We will search for the answer in Hobbes' explanation of the use of language. The philosopher of Malmesbury argues that the use of language is twofold. One is communication with other people, i.e. signifying one's thoughts and passions to other men, which is indispensable for the making of society. Thanks to language, men are capable of giving and understanding orders, which enables them to regulate their mutual relations and thereby to give security to their lives, which are in constant danger of violent death in the state of nature. What is more, language, as well as society, does not only increase the chances of surviving, but also increases the quality of life, because it gives men the opportunity to teach and counsel one another as well as to entertain themselves with - for example - artistic expression. However, these advantages have their correspondent disadvantages, which are the results of the abuses of words. By words, a man can deceive others, teach them what is false and thereby convince them to act contrary to the conditions of society and peace. ${ }^{7}$ Hence, the construction of society, as well as its destruction, depends on the capability of men to communicate their thoughts and passions to other men, from which Hobbes infers that "by speech, man does not become better, but more powerful". ${ }^{8}$

The other, and for this English philosopher more fundamental, profit that we get from speech is marking one's thoughts in order to save them from slipping out of memory and to be able to recall them again by the names that they

See: Thomas Aquinas, Contra Gentiles, IV, 54. Available at: http://dhspriory.org/thomas/ ContraGentiles4.htm\#54 (accessed on September 30, 2016).

See: Aristotle, Politics, in: Jonathan Barnes (ed.), The Complete Works of Aristotle. The Revised Oxford Translation, p. 1988 (1253 a 7-18).

Thomas Hobbes, Leviathan, Basil Blackwell, Oxford 1957, p. 18.

William Molesworth (ed.), Thomae Hobbes Malmesuburiensis Opera Philosophica Quae Latine Scripsit Omnia, V2, London 1839, reprint: Nabu Press, Charleston 2010, p. 88

The problem of the abuse of speech with the purpose of raising a rebellion against legal sovereign is among those of Hobbes' greatest interest. When he writes about the things that weaken and cause the dissolution of a commonwealth, he is mostly concerned with "seditious doctrines" spread among subjects. Some of these are: the opinion that private men can be judges of good and evil actions; the opinion that whatever is done against private consciousness of man is a sin; the opinion that the sovereign is a subject to civil laws; the opinion that the tyrannicide is lawful, etc. See: Thomas Hobbes, De cive. English Version, Clarendon Press, Oxford 1983, reprinted 1998, pp. 145-156; T. Hobbes, Leviathan, pp. 209-218; Thomas Hobbes, Elements of Law, Cambridge University Press, Cambridge 1928, pp. 133-141. That is why Hobbes insists on a tough state control of press and of universities and of everything that is being taught there as well as of everything that is being preached in the pulpits. See: T. Hobbes, De cive, pp. 95-97; T. Hobbes, Leviathan, pp. 116-117).

8

W. Molesworth (ed.), Thomae Hobbes Malmesuburiensis Opera Philosophica Quae Latine Scripsit Omnia, V2, p. 92. 
were marked by. ${ }^{9}$ Thanks to this, men are capable of reason and of science, of which animals, for want of names, are not. ${ }^{10}$ Names that are crucial for the development of reason and science are universal names, common to many things. But, why do some things have a common name? Why do we impose the same name on two separate individual things, but we do not impose this same name on a third individual thing? Is it because of some universal principle that is inherent to those two things, but not to a third one? An affirmative answer to this question would imply an adoption of some kind of realistic position concerning the status of universals. However, this definitely could not be Hobbes' position because of his materialistic and mechanistic ontological and anthropological principles, which are also the basic principles of his theory of language.

This English philosopher embraced the mechanistic explanation of the world, which became very popular among modern philosophers after Galileo's quantification of science that enabled a huge success in the field of experimental science. This science was dealing with moving bodies, expressing their relations in terms of mathematic formulas, but at the same time being silent about the essences or purposes of things. Philosophers were impressed by the results of such a procedure and tried to make something similar in philosophy. The consequence of this was that since then philosophy was not inquiring into forms and purposes of things anymore as its task became describing the mechanic functioning of the material world. This means that the Aristotelian doctrine of the four causes necessary for the explanation of this world was reduced to two causes only - efficient and material cause. Naturally, some philosophers - like René Descartes, the father of modern philosophy - allowed for the existence of another kind of reality, namely spiritual, that could not be explained in this way. But Thomas Hobbes is a thoroughly mechanistic philosopher because, according to him, there is nothing that could not be explained by mechanic causes. That attitude presupposes materialism that excludes any kind of substance from the universe, save material: "for the universe, being the aggregate of all bodies, there is no real part thereof that is not also a body", which implies that "substance and body signify the same thing". ${ }^{11}$ Hobbes makes no exception to this position and applies it directly to man, which brings him to a conclusion that "man is a body". ${ }^{12}$ Though he sometimes speaks of faculties of the body as well as faculties of the mind, ${ }^{13}$ "the mind itself is not a properly existing object for Hobbes". ${ }^{14}$ Mind cannot be an "incorporeal substance" because this expression is for Hobbes nothing but a linguistic nonsense based on a false metaphysics. ${ }^{15}$ Since man is a moving body, his cognition must be explained in terms of mechanic relations, just like everything else in the universe. All of our cognition begins with senses and for this English philosopher sense "is nothing else but original fancy, caused (...) by the pressure, that is, by the motion of external things upon our eyes, ears, and other organs thereunto ordained". ${ }^{16}$ The rest of our cognitive process is exposed in a similar way: imagination is "nothing but a decaying sense", 17 and the train of imaginations is what Hobbes calls a "mental discourse". ${ }^{18}$ Transfer of this mental discourse into a verbal is what speech consists of. As we can see now, "the train of thoughts", which was the basic element in Hobbes' definition of speech, is actually a train of imaginations and not some abstract rational activity. Reason, for Hobbes, is just a particular sort of imagination ${ }^{19}$ and that is why our every thought is concrete: we cannot have a thought of man as such, but our thought is always a thought of some determinate man. ${ }^{20}$ From this follows that "word universal is never the name of any thing existent in nature, nor of any idea or phantasm formed in the 
mind, but always the name of some word" 21 or, differently, "there is nothing universal but names". ${ }^{22}$ And it is this attitude that makes Hobbes become "the chief reviver of nominalism in seventeenth-century English philosophy". ${ }^{23}$

But if there is nothing universal in nature, or in mind, then the imposition of names, which is crucial for the development of science, does not depend on the metaphysical structure of things or on our universal conception of things. The question is: what does it depend on? Hobbes says that "one universal name is imposed on many things, for their similitude in some quality". ${ }^{24}$ But, which quality will be a deciding one? How do we decide whether two things of similar colour should have the same name, or they should not, because they are not of the same shape? To Hobbes, it is a matter of convention because all names are "arbitrarily imposed". ${ }^{25}$ Italian philosopher Arrigo Pacchi recognizes in this some kind of "linguistic covenant" 26 and the consequence of this in Hobbes' philosophy will be a reduction of reason to computation of names and the reduction of science to an "enormous tautology". ${ }^{27}$ Neither reason nor science could be about things, but only about names. The cause of this lies in Hobbes' view, which is quite opposite to the hypothesis that we deduced from his definition of speech. It is the view that language has priority over reason and not the other way round. The thought is not, as man's natural act, a precondition of language, but quite the opposite, it is the artificial result of the right use of speech. This English philosopher argues that man is born with the same natural faculties as any other animal, but may, with the help of

See: T. Hobbes, Leviathan, p. 18.

10

See: T. Hobbes, Elements of Law, p. 14.

11

T. Hobbes, Leviathan, p. 256.

12

William Molesworth (ed.), The English Works of Thomas Hobbes V1, London 1839, reprint Adamant Media Corporation, Boston 2005, p. 45 .

13

See: T. Hobbes, Elements of Law, pp. 1-2.

14

A. P. Martinich, Hobbes, Routledge, New York - London 2005, p. 33.

15

See: T. Hobbes, Leviathan, p. 256.

16

Ibid., p. 8 .

17

Ibid., p. 9. Imagination is for Hobbes the same thing as memory, having only a different name because of the difference in the point of view from which it is being observed. For A. P. Martinich this identification of memory with imagination is a big mistake because "although all imaginings could be traced back ultimately to some sensation, imaginings that are not memories are set free from the requirement that they match the event that caused them. A person can imagine a unicorn but cannot remember one". A. P. Martinich, Hobbes, p. 36 .

18

T. Hobbes, Leviathan, p. 13.

19

See: W. Molesworth (ed.), Thomae Hobbes Malmesuburiensis Opera Philosophica Quae Latine Scripsit Omnia, V2, p. 89.

20

W. Molesworth (ed.), The English Works of Thomas Hobbes V1, p. 60.

21

Ibid., p. 20.

22

T. Hobbes, Elements of Law, p. 15.

23

Stephen K. Land, The Philosophy of Language in Britain. Major Theories from Hobbes to Thomas Reid, AMS Press, New York 1986, p. 19.

24

T. Hobbes, Leviathan, p. 19.

25

W. Molesworth (ed.), The English Works of Thomas Hobbes V1, p. 16.

26

Arrigo Pacchi, Introduzione a Hobbes, Laterza, Roma - Bari 2004, p. 68.

27

Ibid., p. 68 . 
speech, improve these same faculties to such a height, to rank himself above all other living beings. ${ }^{28}$ There is nothing specific that man is born with. Reason, which was from the ancient time recognized as man's differentia specifica, is, according to Hobbes, an acquired virtue, "which is grounded on the right use of speech" 29 and which is "nothing but reckoning (...) of the consequences of general names agreed upon for the marking and signifying of our thoughts". 30 On the other hand, science, this great benefit of men which is possible due to language, will be nothing but "a faithful, correct and accurate nomenclature of things". 31

However, if our reason as well as the whole building of science is based upon speech, there still remains one important question to answer: what is the basis of speech? Where does it trace its origin to? Speaking of the origin of speech in his Leviathan, Hobbes uses a comparison of speech with some human inventions, like that of printing or writing, claiming that "the most noble and profitable invention of all other, was that of speech"; 32 and later in De homine he states that the origin of language "can be nothing else but the will of a man itself". ${ }^{33}$ Thus, in contrast to Aristotle, for Hobbes men are not social, nor rational by nature, nor is the speech something natural to them. Exactly the opposite, language is an artificial human invention, and reason as well as society is just its - equally artificial - consequence.

This theory naturally provokes a further question: if language is purely human invention and, what is more, the kind of invention that enables man to form all of his specific abilities which he does not share with all other animals, what makes him capable of this invention? The train of thoughts or imagination that is being signified by speech is not something specifically human; animals are capable of it, too. How come, then, that they are not capable of language as well? In De mundo Hobbes argues that this is the result of a specific human passion, namely curiosity, which is a desire to know causes of everything, and it is this passion that induces man to make "notes" as helpful means to his memory in search for causes. This enables him then to translate his mental discourse into speech. ${ }^{34}$ Curiosity is not something innate to men because only some basic appetites "are born with men; as appetite of food, appetite of exertion, and exoneration". ${ }^{35}$ All other passions, including curiosity, are the result of experience. It is interesting to note that curiosity is for Hobbes, though a result of experience, a universal human passion. ${ }^{36}$ We may wonder how he can justify the attitude that experience produces some universal human feature. He does not allow the existence of any specific human faculty that every man as such would be born with and that could be further developed by experience. The only thing that distinguishes man from animal in the moment of their birth is their physical constitution. In that regard, the English philosopher argues that "owing to their physical constitution" animals are not capable of any "pleasure other than the carnal". ${ }^{37} \mathrm{He}$ does not explain what causes this difference in physical constitution or what exactly in the physical constitution of men enables the occurrence of a "not-purely-carnal" pleasure, and how this happens. However, evoking physical constitution of men in order to explain universality of human language suggests the image of man as some kind of a "speaking machine", which is inevitably turned on by any kind of experience whatsoever. Even though this image is in perfect accordance with Hobbes' mechanicism, we may agree with R. Peters who claims that "it seems fantastic to suggest that a descriptive language with all its artificiality and arbitrariness" can be explained by mechanic causes, i.e. "simply by the movements of bodies impinging on the sense-organs". ${ }^{38}$ Besides, it is really hard to see how this mechanicist explanation of language can be made 
consistent with the arbitrariness, ${ }^{39}$ which was in De homine emphasised as a peculiarity of human speech compared to the voices of animals. In that work, philosopher of Malmesbury states that voices of animals do not constitute speech because these voices are not "established by the will of animals, but flow by a natural impulse" 40 from their passions. He also used this argument to explain the diversity of human languages in respect of uniformity of animal voices. However, with Hobbes' image of man as a "speaking machine", the difference, between animal voices and human language, disappears. Hence, we may conclude that language as a specific human feature, which is considered as a purely human invention, lacks any plausible explanation of its own ground, even though it grounds all other specific human abilities.

\section{Thomas Reid}

Thomas Reid is very famous for his critique of empiricist philosophers, more precisely, of their doctrine according to which the immediate object of our cognition is an idea or impression inside of our mind, and which he often calls a "system of ideas" that as its final consequence has total scepticism. Even though he himself is an empiricist philosopher, who strongly emphasizes the importance of experiment and observation in our cognition of nature, as well as the importance of reflexion in the research of the human mind, Reid does not think that these are the only sources of our knowledge. According to him, "there are principles of belief in human nature, of which we can give no other account but that they necessarily result from the constitution of our faculties; and that if it were in our power to throw off their influence upon our practise and conduct, we could neither speak nor act like reasonable men". ${ }^{41}$ These lines refer to so-called "common sense principles", common to all humans at all times and in all places. These are also the first principles of our entire knowledge and the reason we have no doubt about the existence of the external material world. However, common sense assures us of the existence of not only corporeal, but of incorporeal reality as well. For Reid it is obvious that incorporeal things exist as well as corporeal, and this is one of the main differences between him and Hobbes, for whom "incorporeal substance" is

28

See: T. Hobbes, Leviathan, p. 16.

29

Ibid., p. 46.

30

Ibid., pp. 25-26.

31

Thomas Hobbes, Thomas White's De Mundo Exaimned, Bradford University Press - Crosby Lockwood Staples, Bradford - London 1976., p. 157.

32

T. Hobbes, Leviathan, p. 18.

33

W. Molesworth (ed.), Thomae Hobbes Malmesuburiensis Opera Philosophica Quae Latine Scripsit Omnia, V2, p. 90.

34

See: T. Hobbes, De Mundo, p. 373.
35

T. Hobbes, Leviathan, p. 32.

36

See: Ibid., p. 69

37

T. Hobbes, De Mundo, p. 373.

38

Richard Peters, Hobbes, Penguin Books, Harmondsworth 1956, p. 134.

39

See: Ibid., p. 123.

40

W. Molesworth (ed.), Thomae Hobbes Malmesuburiensis Opera Philosophica Quae Latine Scripsit Omnia, V2, p. 88.

41

Thomas Reid, Essays on the Intellectual Powers of Man, MIT Press, Cambridge et al. 1969 , p. 652. 
a contradictory concept. While the philosopher of Malmesbury applied his materialism consistently on the human being and conceived the process of human cognition in terms of pure mechanism, Scottish philosopher finds such interpretation of human cognition unacceptable; it is absurd "to think that the impressions of external objects upon the machine of our bodies can be the real efficient cause of thought and perception". ${ }^{42}$ Reid conceives man not just as a body, but as a mind as well, which exerts its activity in the process of cognition.

From what is said above, it is clear that Reid's philosophy differs from Hobbes' in some important anthropological and epistemological issues, which also make different presuppositions for their theories of language. However, in the texts of the two philosophers we can find some similar theses concerning language. For example, the philosopher of Aberdeen claims something very reminiscent of what we have read in Hobbes' works when he says that without language "mankind would hardly be able to attain any degree of improvement above the brutes" ${ }^{43} \mathrm{He}$ also explains language in terms of signs which have their meaning established by some contract or agreement and which we use in two ways: in communication of our thoughts, intentions, purposes and desires to other people, as well as in "clothing our thoughts with words" in order to have a "firmer hold on them". ${ }^{44}$ But, differently from Hobbes, this Scottish philosopher gives priority to the first usage of language, arguing that "a man who had no interactions with other thinking beings would never think of language". ${ }^{45}$ However, this difference of views between the two philosophers is just a reflection of a much deeper difference concerning their opinions on human sociability. Unlike the philosopher of Malmesbury, Thomas Reid holds that "man is by his nature a social animal"; 46 he is led by nature to communicate with others, and for this purpose he is endowed with social intellectual powers as well as with social affections, which are the most basic aspects of his constitution. Social intellectual powers manifest in social operations like asking or receiving information, offering or receiving a testimony, requiring or getting a favour, giving or receiving a command, giving one's word in a promise or in a contract. These operations are called social, because they presuppose society with other thinking beings, but they are also called intellectual, because only intellectual beings can perform them and that is why they are the privilege of men, among all the other living beings on earth. ${ }^{47}$ This is also the reason why language, as a system of artificial signs, established by common agreement or contract, is something peculiar to man. ${ }^{48}$

However, this natural sociability of man and language as his specific feature are bound together on an even more basic level; because this contract, which grounds language, would be impossible without some other means of communication. Differently from Hobbes, who sees language as an entirely human invention, like writing or printing, Reid states:

"Had language in general been a human invention, as much as writing or printing, we should find whole nations as mute as brutes." 49

That is why the philosopher of Aberdeen differentiates between artificial language, which is the invention of men and which consists of artificial signs, and natural language, which is a gift of nature and which consists of natural signs. It is true that animals also use some natural signs in order to communicate, for example, their desire for food, to draw the attention and the like, but they are not endowed with those social intellectual powers that enable men to make a contract and to establish the system of artificial signs in order to develop and enrich their communication. ${ }^{50}$ However, the natural language of 
men does not cease to exist when the artificial one is developed because "it is by natural signs chiefly that we give force and energy to language; and the less language has of them, it is the less expressive and persuasive". ${ }^{1}$

Reid identifies three kinds of natural signs, common to all mankind, and these are: modulations of voice, gestures and facial expressions. We reveal their signification "by a natural principle, without reasoning or experience". 52 It is the nature which has established the relationship between signs and thoughts in the natural language, and it is also the one which taught us how to interpret these signs. As a proof of this, the Scottish philosopher refers to the reactions of little children who, very soon after their birth, may be "put into a fright by an angry countenance" or "may be made merry or sorrowful, by the modulation of musical sounds". ${ }^{53}$ Hence, people of all nations understand and communicate by means of natural language. And since natural language is the necessary condition for the development of any artificial language whatsoever, Reid holds that all languages of the world have some common features "for we find in all languages the same parts of speech, the distinction of nouns and verbs, the distinction of nouns into adjective and substantive, of verbs into active and passive. In verbs we find like tenses, moods, persons, and numbers. There are general rules of grammar, the same in all languages". ${ }^{54}$ These universal features of language, according to Reid, are the proof of the universality of human thinking. Though some authors have noticed that universality of these features has not been proved and that it actually does not have any solid basis in empirical facts, ${ }^{55}$ the aim here is not to pursue a linguistic analysis of

42

Ibid., p. 100.

43

Thomas Reid, An Inquiry into the Human Mind on the Principles of Common Sense, Pennsylvania State University Press 1997, reprint: 2009, p. 50.

44

T. Reid, Essays on the Intellectual Powers of Man, p. 72.

45

Ibid., p. 72.

46

Ibid., p. 55.

47

See: Ibid., p. 71.

48

This is not to say that Reid ever endorsed a social contract theory as propagated by Hobbes, although he maintains that "all artificial language supposes some compact or agreement to affix a certain meaning to certain signs". See: T. Reid, An Inquiry into the Human Mind on the Principles of Common Sense, p. 51. The important difference between him and Hobbes, as shall be shown immediately, lies in the fact that beside this artificial language, which is based on contract, Reid also admits the existence of a natural one, which conditions the very possibility for the contract itself.
49

Ibid., p. 51.

50

See: Ibid., p. 51.

51

Ibid. p. 52.

52

Ibid, p. 60 .

53

Ibid.

54

T. Reid, Essays on the Intellectual Powers of Man, p. 26.

55

Stephen K. Land chooses and analyses six features of language, which this Scottish philosopher considers to be universal and concludes that the universality of neither of these features is demonstrated and that "Reid is in fact simply adopting accepted universals from the tradition of philosophical grammar". See: S. K. Land, The Philosophy of Language in Britain, p. 223. Similarly, K. Schumann and $\mathrm{B}$. Smith state that the distinctions that Reid indicates "hold in fact for those Western languages with which he was more or less acquainted, ranging from Greek and Latin to French and German. Reid's claim that these features exist 'in all languages that are to be found on the face of the earth' is in fact nothing but a 'hypothesis' in Reid's own negative 
particular languages to see if Reid was right or not in his list of linguistic universals. A more fundamental question will be explored: can Reid consistently ground language in human nature considering his philosophical principles?

We have seen that Hobbes, due to his nominalism, was not able to ground language in human nature. Some authors have observed that Reid is trying to oppose the nominalist thesis of other British philosophers. ${ }^{56}$ Indeed, differently from Hobbes, who holds that there is nothing universal but names, Thomas Reid states:

"As general words are so necessary in language, it is natural to conclude that there must be general conceptions, of which they are the signs." 57

But does he really manage to overcome nominalism? First of all, it is clear that his opposition to nominalism of the British philosophers excludes the position of the extreme realism, because, according to him, "every thing that really exists is an individual". ${ }^{58}$ However, when he affirms: "I apprehend that we cannot, with propriety, be said to have abstract and general ideas", ${ }^{59}$ he seems to reject even moderate realism as well as conceptualism and, what is more, he seems to come into contradiction with his former statement. But there is actually no contradiction. What we are dealing with here is actually Reid's specific way of explaining general conceptions, which has not been explored enough yet. As already mentioned above, Thomas Reid rejects the thesis, popular among modern British philosophers, according to which the immediate object of our thought is something inside of our mind, like an idea or impression. What is more, he rejects the very existence of ideas as "a mere fiction of philosophers" ${ }^{60}$ Among these philosophical "fictions", Reid also classifies sensible and intelligible species and phantasms of Aristotle. In short, he does not admit the existence of anything in the mind. In fact, to say that something is "in the mind" is the same for Reid as to say that the mind is the subject of it: just as the table is the subject of its shape and size, so the mind is the subject of its powers, faculties and operations. And this is the only way in which, according to Reid, we may say that something is in the mind. ${ }^{61}$

Then how are we to understand Reid's claim that we do have general conceptions? We will try to do this, first, by attending to his definition of conception:

“The words 'notion' and 'conception' in their proper and most common sense signify the act or operation of the mind in conceiving an object." 62

Hence, "to have a conception" or "to have an idea" is exactly the same as "to conceive". ${ }^{63}$ Reid thinks that this interpretation is in accordance with our ordinary language and our everyday experience. ${ }^{64}$ Of course, we can put this thesis in question, because even our ordinary language differentiates between the expressions "to have an idea" and "to conceive" or "to have a thought" and "to think", that is, between some operation of the mind and the end of that operation. We may add to this that a man actually becomes aware that he has a mind or that he is an intellectual being precisely by reflecting about the ideas that exist inside of his mind. ${ }^{65}$ Thus, this is the moment in which Reid's reasoning is not in accordance with common sense. This becomes explicitly clear when, rejecting the existence of any concepts or ideas in the mind, he is trying to prove that men can conceive things that never existed. ${ }^{66}$ For example, he says we can have as clear and distinct a conception of a winged horse as of a man whom we have just seen, with no inclination to believe that this winged horse ever existed. Of course, we can imagine a winged horse and we 
are thereby in no way obliged to believe in its real existence. However, that does not mean that this winged horse does nowise exist, because in that case it would not be a being - that which exists. That is why we should differentiate between different kinds of beings. The scholastic philosophy knew very well the difference between ens realis and ens rationis, the being that really exists and the being that exists only in the mind. ${ }^{67}$ But Reid does not allow the existence of ens rationis, and this univocal signification of ens brings him to the absurd and contradictory conclusion that we may have a cognition of what is - a thing or a being - that, at the same time, is not.

Now we need to see how this identification of conception with the operation of conceiving affects Reid's understanding of general conceptions. This Scottish philosopher claims that a conception counts as general not because of "the act of the mind in conceiving, which is an individual act", but because of "the object, or thing conceived, which is general". ${ }^{68}$ At first, this seems to contradict the former statement according to which all things that exist are individual. However, we must pay attention to Reid's explanation of "general things". When he says that something is general, he means that it is a common attribute of many things; for example, white colour is a common attribute of the sheet of paper that I am writing on, as well as of the wall that I look at when I raise my eyes. Hence, a general name signifies "those attributes which have been observed to be common to every individual" 69 of the same sort. This, of course, provokes the question about the way in which individuals are being classified in sorts. And Scottish philosopher is very clear about that too:

sense of a conjecture that is not borne out by fact". See: K. Schumann, B. Smith, "Elements of speech act theory in the work of Thomas Reid", History of Philosophy Quarterly 7 (1/1990), pp. 47-669, p. 63, n. 20.

56

See: S. K. Land, The Philosphy of Language in Britain, p. 221; R. Nichols, G. Yaffe, ,Thomas Reid", Stanford Encyclopedia of Philosophy. Available at: http://plato.stanford. edu/entries/reid/ (accessed on July 11, 2016).

57

T. Reid, Essays on the Intellectual Powers of Man, p. 471.

58

Ibid., p. 516.

59

Ibid., p. 515.

60

Ibid., p. 20

61

See: Ibid., p. 7.

62

Ibid., p. 506.

63

See: Ibid., p. 159.

64

See: Ibid., p. 383.
65

See: Juan José Sanguineti, Introduzione alla gnoseologia, Le Minnier, Firenze 2003, p. 84.

66

See: T. Reid, Essays on the Intellectual Powers of Man, pp. 404-405.

67

Following Aristotle, Thomas Aquinas differentiates between the two uses of being: "(1) In one way, it is used apropos of what is divided into the ten genera; (2) in another way, it is used to signify the truth of propositions. The difference between the two is that in the second way everything about which we can form an affirmative proposition can be called a being, even though it posits nothing in reality. It is in this way that privations and negations are called beings; for we say that affirmation is opposed to negation, and that blindness is in the eye. In the first way, however, only what posits something in reality can be called a being. In the first way, therefore, blindness and the like are not beings." See: Thomas Aquinas, De ente et essentia, c. 1. Available at: http:// dhspriory.org/thomas/DeEnte\&Essentia.htm (accessed on December 1, 2016).

68

T. Reid, Essays on the Intellectual Powers of Man, p. 471.

69

Ibid., p. 394. 
"Things are parcelled into kinds and sorts not by nature but by men. (...) Those that agree in certain attributes are thrown into one parcel, and have a general name given them, which belongs equally to every individual in that parcel." 70

Thus, the classification of things into genera and species is a matter of convention and, thus, we have not moved far away from Hobbes' conventionalism and nominalism. Although not a materialist like Hobbes, Reid, because of his nominalism, exactly like Thomas Hobbes, reduces intellect to a sensible function. ${ }^{71}$ Reid's general conception is not a matter of an authentic intellectual cognition, which consists of the apprehension of the essence or nature of a thing. The human mind, according to him, cannot grasp the essence or nature of any individual thing, corporeal or spiritual, but only its attributes. ${ }^{72}$ Reid holds that the knowledge of the essences of individual things is something proper only to the mind of God that created these things. But the real problem here is that there is no specifically identical ontological principle, individualised in all individual beings of the same species, thanks to which each one of them would have the equal essence or nature. For Reid, the real essence of a thing is something extremely individual.$^{73}$ On the other hand, the universality of the nominal essence is the result of the convention among men. ${ }^{74}$

This whole discussion about the universals, which, as we have seen, brings the Scottish philosopher very close to the philosopher of Malmesbury, throws a new light on his attempt to ground language in human nature, because this ground is now compromised. To be more precise, this ground does not really exist! There is no a specifically identical ontological principle in every human being, which makes him to be exactly that - a human being or a being that possesses a human nature. What really does exist is nature or, rather, natures, that are absolutely different for each individual human being. But these natures cannot be the subject of a philosophical inquiry because no science is about particulars. In addition, these natures are beyond the grasp of our mind. The only philosophical knowledge that we may have about human beings must be based on some conventional definition that expresses the nominal essence of a human. However, to make things even more paradoxical, Reid claims that we actually do not have such a definition:

"It is indeed very difficult to fix a definition of so common a word (...)."

Thus, in spite of his explicit statements and his arguments based on some phenomenological observations, Reid has left language with no real, as well as no nominal ground in human nature.

\section{Conclusion}

As we have seen, the main difference between the two British philosophers in the matter of language lies in their answer to the question of whether language is something natural to men or not. Hobbes clearly denies this, declaring that language is a purely human invention, the kind of invention that is crucial for the development of all the other specifically human features. In the circumstances in which there is nothing specifically human that man is born with, the philosopher of Malmesbury is not able to give any solid ground to language as a specific human feature. On the other hand, Reid thinks that language as a human invention must be grounded in the very nature of men, specifically, in their natural language which is correlated to their natural sociability. Hence, at first sight it seems that the Scottish philosopher gives a more satisfying and more persuasive solution to the problem of grounding language. However, 
the philosophical background that Thomas Reid shares with Thomas Hobbes disables him in making his theory consistent.

The philosophical background that we have in mind is a typically modern view, which rejects the Aristotelian hylomorphistic theory about the structure of the sensible world in the name of the mechanistic explanation, which seemed truly scientific to the philosophers of the time. According to the latter, the sensible world is a pure extension, and in some aspect out of reach of the human mind, ${ }^{76}$ because it is something completely different from its spiritual nature. ${ }^{77}$ The seeds of this theory were planted by René Descartes, and they had a strong influence on the thinkers of the following period. Though not all of them were dualists like Descartes, once body and mind were made two different substances, it was easy to discard either of them. For instance, in the case of Thomas Hobbes, the incorporeal substance was the discarded one, and in the case of George Berkeley it was the material one. A common thing to all of them, however, was the rejection of the teachings of Aristotle and

70

Ibid., pp. 393-394.

71

See: J. J. Sanguineti, Introduzione alla gnoseologia, p. 89.

72

See: T. Reid, Essays on the Intellectual Powers of Man, p. 5.

73

"... individual things (...) have a real essence or natural constitution from which all their qualities flow: but this essence our faculties do not comprehend: they are therefore incapable of definition; for a definition ought to comprehend the whole nature or essence of the thing defined." See: Ibid., pp. 394-395. 74

In this distinction between the real and the nominal essence, Reid is actually following John Locke, who in his Essay Concerning Human Understanding differentiates between "the real internal, but generally (in substances) unknown constitution of things" and "artificial constitution of genus and species". He thinks that "these two sorts of essences (...) may not unfitly be termed, the one real, the other nominal essence". See: John Locke, An Essay Concerning Human Understanding, Vol. 2, Dover Publishing, New York 1959, pp. $26-27$

75

T. Reid, Essays on the Intellectual Powers of Man, p. 476. That is why Reid proposes in particular cases of a "monstrous birth of a woman" to leave the evaluation of whether it is human or not "to the determination of a judge or of a jury" (Ibid., p. 476). Thus, according to this Scottish philosopher, the question whether someone is human or not is a matter of a judge's evaluation. This attitude can have very dangerous consequences in practical life, because in circumstances in which we do not know what the nature of man is, every "birth of a woman" may be declared "monstrous" and brought out to court and, thus, left to mercy of a particular judge. In this view, Reid is again somehow close to the philosopher of Malmelsbury, who says that "upon occasion of some strange and deformed birth, it shall not be decided by Aristotle, or the philosophers, whether the same be a man, or no, but by the laws". See: T. Hobbes, Elements of Law, p. 150. Though Hobbes suggests to resolve these cases on a more general level than Reid, there still remains the problem of practise, because, this way, the most basic anthropological questions are being submitted to a political decision.

76

Modern philosophers had pretty different views concerning the existence of the material world: R. Descartes, for instance, had to prove it, while N. Malebranche thought that such a proof is impossible and appealed to Revelation as a trustful testimony of the existence of the material reality. On the other hand, G. Berkeley completely denied the existence of material substance. Relying on his common sense principles, T. Reid found the existence of the material world undeniable. However, rejecting hylomorphism, he made the essence of the material things completely unknown to the human mind.

77

In support of this, let us mention how Reid says we often use analogical reasoning in what concerns the mind "but all arguments, drawn from analogy, are still the weaker, the greater disparity there is between the things compared; and therefore must be weakest of all when we compare body with mind, because there are no two things in nature more unlike". See: T. Reid, Essays on the Intellectual Powers of Man, p. 50. 
the Scholastics according to which every individual sensible thing contains within itself substantional form which makes it open to the human mind and enables us universal knowledge of the sensible reality. By dismissing form, modern thinkers developed a tendency to embrace nominalism. Hence, they are prone to think of the sensible world and - what is more - of the whole universe as of something unintelligible, because it contains not a mark of intelligence, but is a result of God's arbitrariness. The consequence of this on the anthropological level is not just that human nature is something unknowable for us, but also that human nature in the sense of a ontological principle specifically equal in all members of the human species does not exist anymore. Human nature has become something extremely individual, and so every human being has his own nature, absolutely different from the natures of all other beings that we may call human, and, as such, hidden to our cognitive powers. The only way in which we may speak of some "general" human nature is to agree upon some definition, made of certain attributes, generally accepted as human. Thus, Reid could consistently uphold that language is something natural to a human being, only because it is something that is generally accepted as a common attribute of all men and expressed in the nominal definition of human. However, we could see how Reid clearly states that such a definition actually does not exist. Hence, we may conclude that Reid had a fair, but, unfortunately, failed attempt of grounding language in human nature, and that neither of the two philosophers managed to give ground to language as a specifically human feature.

\title{
Ivana Knežić
}

\section{Problem utemeljenja jezika kao ljudske specifičnosti u filozofiji Thomasa Hobbesa i Thomasa Reida}

\begin{abstract}
Sažetak
U članku istražujemo kakvo utemeljenje jezika, kao specifično ljudske sposobnosti, nude djela dvojice predstavnika moderne britanske filozofije: Thomasa Hobbesa i Thomasa Reida. Oba filozofa slažu se da je jezik ljudska specifičnost, koja čovjeku služi za izražavanje njegovih misli. Ipak, prema Hobbesu, jezik nije samo ljudska specifičnost, nego je to ujedno temeljna ljudska sposobnost koja omogućuje formiranje svih drugih sposobnosti-uključujući i racionalnu misao - koje čovjeka izdižu ponad animalnoga svijeta. Jezik, stoga, nije nešto što proizlazi iz ljudske naravi, nego upravo suprotno, nešto što na određeni način uvjetuje nastanak same čovječnosti. Istovremeno, problem utemeljenja samoga jezika ostaje neriješen u filozofiji Thomasa Hobbesa. S druge strane, premda je Reid vidio sve svjetske jezike kao sustave umjetnih znakova koje su ljudi načinili, on je njihov temelj smjestio u samu ljudsku narav, točnije, u nešto što on naziva "naravnim jezikom", zajedničkim svim ljudima kao racionalnim i društvenim bićima. No, ovaj pokušaj utemeljenja jezika u ljudskoj naravi nailazi na određene poteškoće, što će rješenje, koje nudi škotski filozof, učiniti nekonzistentnim. Te poteškoće, pak, unatoč svim razlikama koje postoje između dvojice filozofa, ukazuju na njihovo zajedničko filozofsko naslijeđe.
\end{abstract}

\section{Ključne riječi}

Thomas Hobbes, Thomas Reid, jezik, nominalizam, ljudska narav 


\section{Ivana Knežić}

\section{Das Problem der Begründung der Sprache als spezifische menschliche Eigenschaft in der Philosophie von Thomas Hobbes und Thomas Reid}

\section{Zusammenfassung}

Der Artikel erforscht die Grundlagen der Sprache als spezifische menschliche Fähigkeit, in den Werken zweier Vertreter der modernen britischen Philosophie: Thomas Hobbes und Thomas Reid. Beide teilen das Verständnis der Sprache als eines spezifischen menschlichen Merkmals, wodurch der Mensch seine Gedanken ausdrückt. Aber nach Hobbes ist die Sprache nicht nur eine spezifische menschliche Fähigkeit, sondern auch die Grundfähigkeit eines Menschen, die ihm die Formung aller anderen Fähigkeiten - einschließlich seines rationalen Denkens - ermöglicht, das ihn über die Welt der Tiere hebt. Die Sprache ist also nicht etwas, das aus der menschlichen Natur entspringt, sondern das Gegenteil, es ist etwas, das in gewisser Weise die Entstehung der Menschheit selbst bedingt. Gleichzeitig bleibt das Problem der Begründung der Sprache selbst in der Philosophie von Thomas Hobbes ungelöst. Auf der anderen Seite, obwohl Thomas Reid alle Sprachen der Welt als Systeme von künstlichen Zeichen der Menschen sieht, setzt er die Begründung der Sprache in die menschliche Natur, genauer, in das, was er die „natürliche Sprache" nennt, was allen Menschen, als rationellen und sozialen Wesen, gemeinsam ist. Doch dieser Versuch, eine Sprache in der menschlichen Natur zu gründen, stand vor einigen Schwierigkeiten, welche die von diesem schottischen Philosophen angebotene Lösung inkonsistent machten. Diese Schwierigkeiten hingegen, trotz aller Unterschiede zwischen den beiden Philosophen, implizieren ihren gemeinsamen philosophischen Hintergrund.

\section{Schlüsselwörter}

Thomas Hobbes, Thomas Reid, Sprache, Nominalismus, menschliche Natur

\section{Ivana Knežić}

\section{Problème de fondation du langage comme spécificité} humaine dans la philosophie de Thomas Hobbes et de Thomas Reid

\section{Résumé}

Le présent travail explore les fondations du langage, en tant que facultés spécifiquement humaines, dans les cuvres de deux représentants de la philosophie britannique moderne, en l'occurrence Thomas Hobbes et Thomas Reid. Tous les deux s'accordent à dire que le langage est une spécificité humaine qui sert l'homme à exprimer ses idées. Toutefois, si l'on en croit Hobbes, le langage est non seulement une spécificité humaine, mais également la capacité première des hommes qui les aide à former toutes les autres capacités, y compris la pensée rationnelle qui, à son tour, leur permet de s'élever au-dessus du monde animal. Par conséquent, le langage n'est pas quelque chose qui découle de la nature humaine. Au contraire, dans l'esprit du chercheur anglais, le langage conditionne l'avènement de leur propre humanité. Raison pour laquelle le problème de fondation du langage demeure non résolu dans la philosophie de Thomas Hobbes. Par contre, bien que Reid ait envisagé les langues étrangères comme systèmes de signes artificiels faits par les hommes, il croit pouvoir dire que leur fondement se trouve dans la nature humaine elle-même, ou pour être plus précis, dans ce qu'il appelle le "langage naturel", commun à tous les êtres humains rationnels et sociaux. Cependant, cette thèse selon laquelle le langage serait étroitement lié à la nature humaine a rencontré quelques difficultés, ce qui, à nos yeux, rend la démarche du philosophe écossais incohérente. Enfin, malgré toutes les différences qui existent entre les deux philosophes, ces difficultés indiquent indubitablement leur héritage philosophique commun.

\section{Mots-clés}

Thomas Hobbes, Thomas Reid, langage, nominalisme, nature humaine 